\title{
Makro- és mikroelem-tartalom összehasonlítása almaültetvények talajában
}

\author{
NAGY PÉTER TAMÁS
}

Debreceni Egyetem, Agrártudományi Centrum, Debrecen

\section{Bevezetés}

A gyümölcstermesztésben a fenntartható és környezetkímélő termesztés megvalósítása napjaink egyik legfontosabb feladata. A környezetkímélő gyümölcstermesztési technológiák közül leggyakrabban az integrált és az ökológiai termesztési formákat alkalmazzák. Az integrált és ökológiai gyümölcstermesztés számos technológiai elemben eltérést mutat, a legmeghatározóbb különbségek azonban a tápanyag-gazdálkodásban és a növényvédelemben találhatók közöttük (SOLTÉSZ \& SZABÓ, 1997). Az ökológiai termesztésben csak szerves alapanyagú trágyák, míg az integráltban mütrágyák is alkalmazhatók a tápanyag-visszapótlásra, természetesen a környezetvédelmi szempontok figyelembe vételével. A gyümölcsösök ökológiai növényvédelmében a réz- és a kéntartalmú, valamint a természetes alapú készítmények használhatók, míg az integrált növényvédelemben számos szintetikus hatóanyagú, de környezetkímélö kémiai készítmény használata is engedélyezett (SOlTÉSZ \& SZABÓ, 1997; Holb \& HeIJne, 2001; Holb et al., 2004). Az almatermesztés területén számos hazai és külföldi vizsgálat igazolta a két környezetkímélő rendszer hasonlóságait és különbségeit a fitotechnika és a növényi károsítók vonatkozásában (BUBÁN et al., 1979; GONDA, 1979, 2003, 2005; BLOOMERS, 1994; BALÁzS et al., 1997; ElLIS et al., 1998; GONDA et al., 2000, 2001; HolB et al., 2003a,b).

Az integrált és ökológiai gyümölcsösök - ezen belül az almaültetvények - talajaiban mérhető tápanyagmennyiségekről és ezek változásairól azonban sokkal kevesebb információval rendelkezünk (HOPKINS-CLARK, 1995; GLOWER et al., 2000; WERNER, 1997). A modern és intenzív, integrált és ökológiai almaültetvények talajjellemzőinek összehasonlító vizsgálatára pedig, csak HOPKINS-CLARK (1995) amerikai kontinensen végzett munkája említhető.

Vizsgálataink célja a növények számára felvehető, könnyen oldható tápanyagtartalmak meghatározása és összehasonlítása volt integrált és ökológiai almaültetvényben.

Postai cím: NAGY PÉTER TAMÁS, Debreceni Egyetem, Agrártudományi Centrum, Mezőgazdasági Kémiai Tanszék, 4032 Debrecen, Böszörményi út 138. E-mail: nagypt@ helios.date.hu 


\section{Vizsgálati anyag és módszer}

A mintázott almaültetvény jellemzői. - Vizsgálatainkat a Debreceni Egyetem Agrártudományi Centrumának pallagi kísérleti telepén 1997-ben telepített, 1 ha területü alma fajtagyüjteményben végeztük. Az ültetvényt M 26-os alanyon $4 \times 1,5$ m sor- és tőtávolságra telepítették. A 40 almafajtából álló gyüjteményt telepítést követően két részre: az egyikben integrált, a másikban ökológiai almatermesztés folyik.

Az integrált ültetvényrész 9, az ökológiai 8 sorból áll, melyek soronként 12 (A,...L jelzéssel) - egyenként 7 fából álló - parcellából épülnek fel. A két ültetvényrészt sövénykerítés választja el.

Az általunk kiválasztott fajták 3 ismétlésben szerepelnek a randomizált elrendezésủ parcellákon (1. ábra).

Trágyázási gyakorlat a vizsgált ültetvényekben. - Az ökológiai ültetvényrész 2000 és 2002 tavaszán 25 t/ha istállótrágyát kapott, melynek összetételét - mivel ennek meghatározása nem történt meg - közepes minőségünek vettük.

Az integrált ültetvényrész 1997-2003 között minden évben, lombhullás után 250 kg/ha NPK komplex $(16,5-16,5-16,5)$ mütrágyát kapott. Kiegészítésként pedig, kora tavasszal $50 \mathrm{~kg} /$ ha $\mathrm{N}$-nek megfelelő $\mathrm{NH}_{4} \mathrm{NO}_{3}$ is kijuttatásra került. Az éves adagokon túl ez az ültetvényrész 2002 öszén 4 t/ha mésztrágyát (cukorgyári mésziszap formájában, melynek $\mathrm{CaCO}_{3}$-tartalmát 50\%-nak vettük), valamint 2003 novemberében 25 t/ha istállótrágyát is kapott.

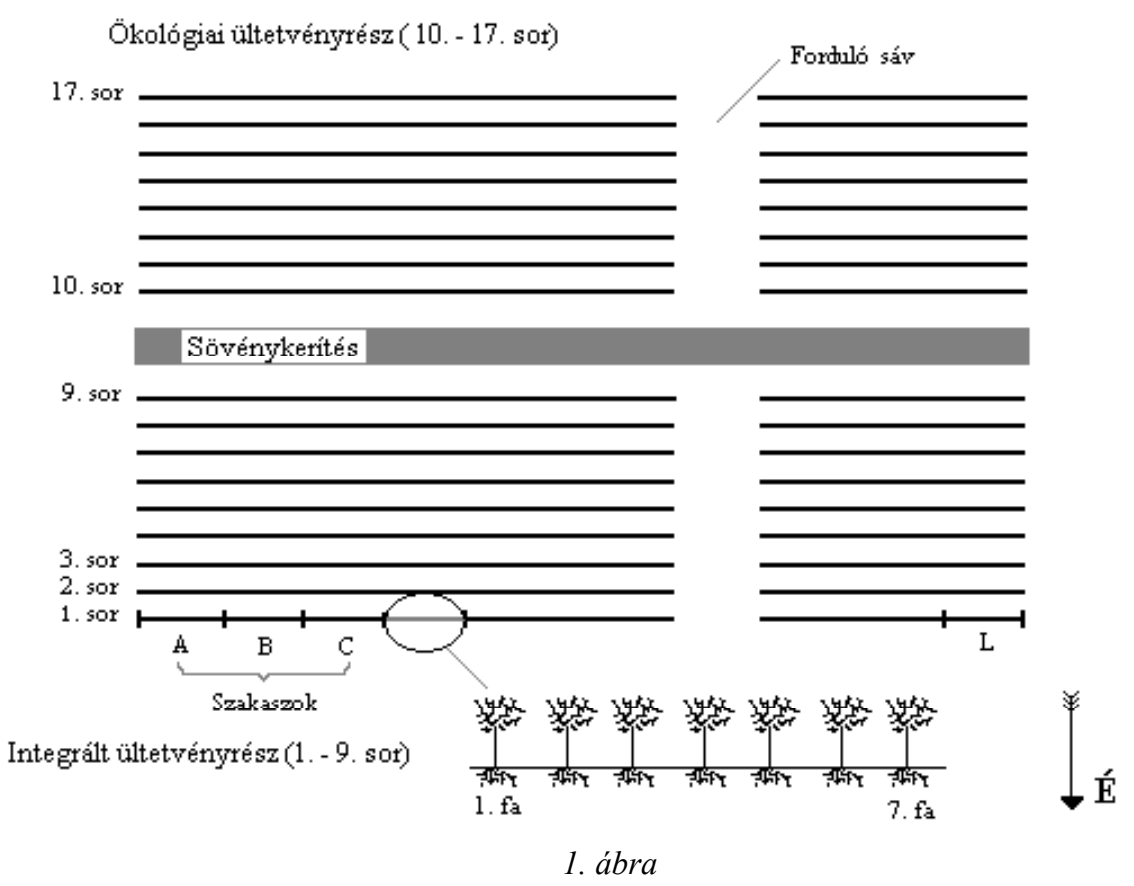

A vizsgált almaültetvény terepi elrendezése 
A 2004-ben tápanyagpótlás nem történt egyik ültetvényrészben sem.

Az alkalmazott trágyakezelések és az általuk kijuttatott tápelemmennyiségek becsült adatai az 1. táblázatban láthatók. A szerves- és mütrágya kijuttatása egyenletes kiszórással, vízszintes dobos, hátul szóró istálló- ill. röpítőtárcsás mütrágyaszóróval történt.

\section{1. táblázat}

Az almaültetvény integrált és ökológiai ültetvényrészében alkalmazott kezelések és az általuk kijuttatott tápelemmennyiségek (becsült átlagok)

\begin{tabular}{|c|c|c|c|c|c|c|}
\hline \multirow{5}{*}{$\begin{array}{l}\text { (1) } \\
\text { Év }\end{array}$} & \multicolumn{3}{|c|}{$\begin{array}{c}\text { (2) } \\
\text { Integrált ültetvényrész }\end{array}$} & \multicolumn{3}{|c|}{ (3) } \\
\hline & \multicolumn{6}{|c|}{ (4) trágyakezelés } \\
\hline & \multicolumn{3}{|c|}{$\begin{array}{c}250 \mathrm{~kg} / \mathrm{ha} / \text { év NPK-komplex } \\
50 \mathrm{~kg} / \mathrm{ha} / \text { év } \mathrm{NH}_{4} \mathrm{NO}_{3} \\
4 \mathrm{t} / \mathrm{ha} \text { cukorgyári mésziszap (2002) } \\
25 \mathrm{t} / \text { ha istállótrágya }(2003)\end{array}$} & \multicolumn{3}{|c|}{$\begin{array}{c}25 \text { t/ha/2 év istállótrágya } \\
(2000,2002)\end{array}$} \\
\hline & \multicolumn{6}{|c|}{ (5) kijuttatott tápelemmennyiségek, $\mathrm{kg} / \mathrm{ha} / \mathrm{év}$} \\
\hline & $\mathrm{N}$ & $\mathrm{P}_{2} \mathrm{O}_{5}$ & $\mathrm{~K}_{2} \mathrm{O}$ & $\mathrm{N}$ & $\mathrm{P}_{2} \mathrm{O}_{5}$ & $\mathrm{~K}_{2} \mathrm{O}$ \\
\hline 2000 & \multirow{4}{*}{$41,25+50$} & \multirow{4}{*}{41,25} & \multirow{4}{*}{41,25} & 37,5 & 37,5 & 75 \\
\hline 2001 & & & & 25 & 17,5 & 37,5 \\
\hline 2002 & & & & 37,5 & 37,5 & 75 \\
\hline 2003 & & & & 25 & 17,5 & 37,5 \\
\hline 2004 & 37,5 & 37,5 & 75 & - & - & - \\
\hline
\end{tabular}

Megjegyzés: Az istállótrágya tápanyag-szolgáltatásának becslése SARKADI (1975) alapján történt

A talajmintavétel módja. - Talajmintáink 5 kiválasztott almafajta (Jonagold, Idared, Red Elstar, Egri piros és Remo) parcelláiról származtak mind az integrált, mind az ökológiai ültetvényrészben. A fajták kiválasztása gyümölcstermesztési és -védelmi szempontokon alapult. Két ventúriás varasodásra rezisztens (Remo, Egri Piros), két ventúriás varasodásra közepesen fogékony (Idared, Red Elstar), valamint egy nagyon fogékony almafajtát (Jonagold) választottunk ki. A kiválasztást alátámasztotta az is, hogy a pallagi ültetvényben a korábbi termesztési vizsgálatokat is elsősorban ezeken a fajtákon végezték (HOLB, 2000; GONDA et al., 2000, 2001).

A talajmintavétel a $0-20 \mathrm{~cm}$-es rétegböl történt, parcellánként 3-3 pontmintát vettünk. A minták a parcellák közepéről, és széleiről származtak, úgy, hogy a parcellák szélétől számítva 1-1 m-t elhagytunk. Az egy parcelláról származó pontminták összeöntéséből kaptuk a parcellára jellemző átlagmintát. A három ismétlésben beállított fajták parcelláinak átlagmintáiból, a vizsgált öt fajta alapján képeztük az ültetvényrészre jellemző mintát, amely így összesen $3 \times 5=15$ minta átlagából tevődött össze. A szignifikáns differencia értékét ennek megfelelően számoltuk.

Tájékozódó jelleggel, a vizsgált terület talajának jellemzésére, a kísérlet mellöl (a sarkoknál, ill. az oldalfelezőknél) vettünk talajmintát és meghatároztuk a fontosabb talajparamétereket. Mintavételezésre tavasszal (IV. hó), ill. ősszel (X. hó) került sor: 2002-ben április 16-án és október 23-án; 2003-ban április 29-én és október 16-án, 2004-ben április 27-én és október 8-án. 
A talajminták makro- és mikroelem-tartalmának laboratóriumi vizsgálata. - A talajminták laboratóriumi vizsgálata során a $\mathrm{N}$ - és $\mathrm{P}$-frakciók mellett a $\mathrm{pH}$ és a kálium mennyiségének meghatározására $0,01 \quad \mathrm{M} \mathrm{CaCl}_{2}$ kivonószert használtunk (HoubA et al., 1986). A 0,01 $M \mathrm{CaCl}_{2}$-os kivonatból a $\mathrm{N}$ - és P-frakciók mennyiségét fotometriás úton, a káliumot emissziós lángfotometriával mértük. A pH értékét a talaj szuszpenzióból határoztuk meg.

A talajok Ca-, Mg- és mikroelem-tartalmának vizsgálatára a Lakanen-Erviö ( $\mathrm{NH}_{4}$-acetát + EDTA) kivonószert használtuk (MSz-20135:1999).

$\mathrm{Az} \mathrm{NH}_{4}$-acetát + EDTA kivonatban a kalcium és magnézium, illetve a mikroelemek mennyiségét láng atomabszorpciós technikával, míg a káliumét ugyancsak emissziós lángfotometriás módszerrel határoztuk meg.

A talaj humusztartalmát szárazégetéses (dry combustion) módszerrel (NAGY, 2000) meghatározott szerves-C-tartalomból számítottuk (BUZÁs, 1988; FILEP, 1995).

A minta-előkészítés során a talajmintákat szellős helyen, szabadban, léghőmérsékleten, 1-1,5 cm rétegben kiterítve szárítottuk, $1 \mathrm{~mm}$-es szitán szitáltuk, homogenizáltuk majd a vizsgálatig müanyag dobozokban tároltuk.

\section{Vizsgálati eredmények és értékelésük}

A vizsgált terület homok textúrájú, kovárványos barna erdőtalaj. Arany-féle kötöttsége 28; $\mathrm{CaCl}_{2}$-os pH-ja 4,62; hidrolízises aciditása 8,16; humusztartalma $0,59 \%$. Teljes C-, ill. N-tartalma 0,34, ill. 0,043\%. Sótartalma 0,002\%. A vizsgált terület - a talajtípusból adódóan - savanyú kémhatású, kis humusztartalmú, ásványi kolloidokban szegény.

Az integrált gazdálkodású terület minden évben nagyobb termést szolgáltatott, mint az ökológiai gazdálkodású (GONDA, 2005).

A 0,01 $\mathrm{M} \mathrm{CaCl}_{2}$ kivonatban mért $\mathrm{pH}$, makrotápanyag-formák valamint a humusztartalom alapján a következő megállapítások tehetőek:

A talaj $0,01 M \mathrm{CaCl}_{2}$ kivonószerben mért $p H$-értéke - a terület talajtípusának megfelelően - savanyú kémhatást mutatott. A vizsgálat hároméves periódusában a pH-érték az integrált gazdálkodású területen 5,30-5,65; míg az ökológiai területen 4,75-5,53 között szórt (2. táblázat). A talaj pH-értéke az integrált területen az almára meghatározott optimum tartomány alsó részében, az ökológiai területen az optimum tartomány alatt van (PAPP \& TAMÁSI, 1979).

A két ültetvényrész átlag pH-jában mutatkozó mérsékelt különbség az eltérő tápanyagpótlás, ill. az integrált ültetvényrészben alkalmazott mésztrágyázás hatásával magyarázható.

A talaj humusztartalma a talajtípusra jellemzö talajképző folyamatok miatt kicsi. Értéke 0,86-1,00, ill. 0,67-0,84 között szórt az integrált, ill. az ökológiai gazdálkodású terület talajában. A humusztartalomban mutatkozó különbségek, feltehetően a mintázott területek talajainak eredendő inhomogenitására vezethetők vissza. 


\section{2. táblázat}

A $0,01 \mathrm{MCaCl}_{2}$-oldható $\mathrm{N}$-formák mennyisége $(\mathrm{mg} / \mathrm{kg})$, a humusztartalom $(\%)$ és a $\mathrm{pH}$ az integrált és ökológiai termesztési mód függvényében (a tavaszi és őszi mintavételek átlagában, $\mathrm{n}=15)(2002-2004)$

\begin{tabular}{|c|c|c|c|c|c|c|}
\hline \multirow{2}{*}{$\begin{array}{c}\text { Termesztési } \\
\text { mód }\end{array}$} & $\mathrm{NO}_{3}{ }^{-}-\mathrm{N}$ & $\mathrm{NH}_{4}^{+}-\mathrm{N}$ & $\begin{array}{c}(2) \\
\text { Szerves-N } \\
\end{array}$ & $\begin{array}{c}\text { (3) } \\
\text { Összes-N }\end{array}$ & \multirow{2}{*}{$\begin{array}{c}(4) \\
\text { Humusz } \\
\%\end{array}$} & \multirow[t]{2}{*}{$\mathrm{pH}$} \\
\hline & \multicolumn{4}{|c|}{$\mathrm{mg} / \mathrm{kg}$} & & \\
\hline \multicolumn{7}{|c|}{2002 tavasz } \\
\hline a) integrált & 5,66 & 1,15 & 4,39 & 11,20 & 1,00 & 5,50 \\
\hline b) ökológiai & 1,36 & 0,13 & 3,35 & 4,74 & 0,81 & 4,75 \\
\hline c) $\mathrm{SzD}_{5 \%}$ & 1,76 & 0,66 & 0,49 & 2,43 & 0,07 & 0,33 \\
\hline \multicolumn{7}{|c|}{2002 ösz } \\
\hline a) integrált & 2,87 & 2,50 & 3,41 & 8,79 & 0,93 & 5,30 \\
\hline b) ökológiai & 0,76 & 1,28 & 3,05 & 5,10 & 0,84 & 5,02 \\
\hline c) $\mathrm{SzD}_{5 \%}$ & 0,93 & 0,56 & 0,41 & 1,41 & 0,06 & 0,24 \\
\hline \multicolumn{7}{|c|}{2003 tavasz } \\
\hline a) integrált & 7,82 & 3,56 & 3,56 & 14,94 & 0,87 & 5,46 \\
\hline b) ökológiai & 1,54 & 1,30 & 2,72 & 5,56 & 0,74 & 5,18 \\
\hline c) $\mathrm{SzD}_{5 \%}$ & 2,10 & 1,09 & 0,35 & 3,24 & 0,06 & 0,25 \\
\hline \multicolumn{7}{|c|}{2003 ösz } \\
\hline a) integrált & 2,35 & 0,56 & 3,77 & 6,68 & 0,86 & 5,37 \\
\hline b) ökológiai & 0,96 & 0,89 & 2,79 & 4,64 & 0,72 & 5,03 \\
\hline c) $\mathrm{SzD}_{5 \%}$ & 0,63 & 0,35 & 0,51 & 1,24 & 0,05 & 0,16 \\
\hline \multicolumn{7}{|c|}{2004 tavasz } \\
\hline a) integrált & 1,25 & 0,66 & 3,83 & 5,74 & 0,98 & 5,63 \\
\hline b) ökológiai & 0,76 & 0,47 & 2,82 & 4,06 & 0,74 & 5,25 \\
\hline c) $\mathrm{SzD}_{5 \%}$ & 0,36 & 0,14 & 0,62 & 1,05 & 0,13 & 0,34 \\
\hline \multicolumn{7}{|c|}{2004 ösz } \\
\hline a) integrált & 1,83 & 0,84 & 3,08 & 5,75 & 0,94 & 5,65 \\
\hline b) ökológiai & 0,62 & 0,79 & 2,68 & 4,09 & 0,67 & 5,53 \\
\hline c) $\mathrm{SzD}_{5} \%$ & 0,53 & 0,31 & 0,63 & 1,06 & 0,09 & 0,34 \\
\hline d) Integrált átlag & 3,63 & 1,55 & 3,67 & 8,85 & 0,93 & 5,49 \\
\hline e) Ökológiai átlag & 1,00 & 0,81 & 2,90 & 4,70 & 0,75 & 5,13 \\
\hline
\end{tabular}

A 0,01 $\mathrm{M} \mathrm{CaCl}_{2}$ oldható $\mathrm{NO}_{3}{ }^{-}-\mathrm{N}$-tartalom az integrált gazdálkodású területen szignifikánsan nagyobb, mint az ökológiai ültetvényrész talajában, ami az integrált területen alkalmazott direkt nitrátbevitellel, a nagyobb N-adagokkal, ill. a kiegészítő mü- és mésztrágyázással magyarázható (1. és 2. táblázat).

Megállapítható, hogy mind az integrált, mind az ökológiai ültetvényrész talajának $\mathrm{NO}_{3}{ }^{-} \mathrm{N}$-tartalma jelentős szezonális ingadozást mutat. A vizsgált három év tavaszi mintavételeiből származó mintákban nagyobb $\mathrm{NO}_{3}{ }^{-}-\mathrm{N}$-tartalmat mértünk, mint az ősszel vett mintákban. Eredményeink a talajban lejátszódó N-átalakulási folyamatok érzékenységével, a tápelemigény évközi változásával, valamint a trágyázási időpontokkal magyarázhatóak. 
Az integrált ültetvényrész talajában, a 2004-es vizsgálati évben mért kisebb $\mathrm{NO}_{3}{ }^{-}-\mathrm{N}$-tartalom az elmaradó tavaszi N-kiegészítéssel, ill. az előző évi mütrágyázás helyett alkalmazott szervestrágyázással értelmezhető.

A talaj 0,01 $\mathrm{M} \mathrm{CaCl}_{2}$ oldható $\mathrm{NH}_{4}{ }^{+}-\mathrm{N}$-tartalma az integrált gazdálkodású területen (a 2003. öszi mintavétel adatait kivéve) nagyobb, mint az ökológiai gazdálkodású területen. Megállapítható továbbá, hogy a talaj $\mathrm{NH}_{4}{ }^{+}-\mathrm{N}$-tartalmának szezonális ingadozása kisebb mértékü, mint a $\mathrm{NO}_{3}^{-}{ }^{-} \mathrm{N}$-tartalomé - függetlenül az ültetvényrésztől (2. táblázat).

A nitrát/ammónium arány eltérést mutat a két ültetvényrészben, ami - összhangban a mért talaj $\mathrm{pH}$-értékekkel - megerősíti azt a tapasztalatot, hogy a savanyú kémhatású homoktalajokon elsősorban a nitrifikációs folyamat gátolt (BOHN et al., 1985).

A talaj 0,01 $\mathrm{M} \mathrm{CaCl}_{2}$-oldható szerves- $\mathrm{N}$ frakciójának mennyisége - függetlenül az alkalmazott termesztési technológiától és mintavételi időponttól - összemérhető az ásványi formák mennyiségével (2. táblázat).

A szerves- $\mathrm{N}$ mennyisége az integrált ültetvényrész talajában nagyobb, mint az ökológiai gazdálkodású terület talajában, ami összhangban van az ott mért nagyobb humusztartalommal. Adatainkból megállapítható, hogy szezonálisan legkevésbé a szerves-N frakció mennyisége ingadozott a vizsgált $\mathrm{N}$-frakciók közül a hároméves vizsgálati időtartam alatt.

A szerves- $N / o ̈ s s z e s-N$ arány az integrált ültetvényrészben 24-67\% között, míg az ökológiai gazdálkodású területen 49-71\% között változott (2. táblázat).

A könnyen oldható, mobilizálható szerves-N frakció tehát részarányát tekintve nagyobb az ökológiai ültetvényrészben, mint az integrált ültetvényrész talajában, ami az ökológiai területen alkalmazott szervestrágyázással és a pH-adatokból következő kedvezőtlenebb mineralizációs körülményekkel magyarázható.

A 2003 novemberében az integrált ültetvényrészben az NPK-mütrágya helyett kijuttatott szerves trágya hatása ennél a frakciónál is kifejezett. A vizsgált $\mathrm{N}$ frakciók mennyiségi arányai a szerves-N forma részarány növekedésének irányába tolódtak el (2. táblázat).

Adataink megerősítik azokat a korábbi megállapításokat, melyek szerint a savanyú kémhatású, kis tápanyagtőkével rendelkező, homok textúrájú talajokon jelentős - az ásványi N-frakciók mennyiségével összemérhető mennyiségü - könnyen oldható, mobilis szerves-N van jelen (LOCH, 1999; LAZÁNYI et al., 2002, 2003).

Az ökológiai gazdálkodású almaültetvény talajában mért jelentős részarányú szerves-N frakció felhívja a figyelmet a természetes eredetủ tápanyagpótláson alapuló termesztési mód homoktalajokon való alkalmazhatóságára, ill. jelentőségére, azzal a feltétellel, hogy ezzel párhuzamosan elő kell segíteni - a talajtulajdonságok javításával - a tápanyagok nagyobb mértékü hasznosulását.

A szerves- $\mathrm{N}$ vizsgálati adatok rámutatnak ugyanis, hogy a szervestrágyázással kijuttatott tápanyagok - bár potenciálisan jelen vannak a talajban - a kedvezötlen adottságok és az alkalmazható talajmüvelés miatt csak vontatottan és kismértékben érvényesülnek, azaz ilyen területeken az ökológiai gazdálkodást pusztán szervestrágyázásra alapozni nem lehet (PAPP \& TAMÁSI, 1979; SOLTI, 2000; SELÉNDY, 1997). 
A talaj 0,01 $\mathrm{M} \mathrm{CaCl}{ }_{2}$-ban oldható összes-N-tartalma a vizsgált egyes frakciók mennyiségének eredőjeként alakult. Az integrált kezelésben részesülő terület talajának 0,01 $\mathrm{M} \mathrm{CaCl}_{2}$-ban oldható összes-N-tartalma meghaladta az ökológiai gazdálkodású területen mért értéket, ami az eltérő N-terhelésekkel és az egyedi frakcióknál említett folyamatokkal értelmezhetö.

A talaj 0,01 $\mathrm{M} \mathrm{CaCl}{ }_{2}$-ban oldható összes foszfát-P-tartalma jelentös eltérést mutat az integrált és az ökológiai termesztésü területnél (3. táblázat). Az integrált terület talajában átlagosan másfél-kétszer annyi $0,01 \mathrm{M} \mathrm{CaCl}_{2}$-ban oldható összes foszfátot mértünk, mint az ökológiai gazdálkodás talajában.

\section{3. táblázat}

A 0,01 $M \mathrm{CaCl}_{2}$-oldható P-formák, valamint a $0,01 \mathrm{M} \mathrm{CaCl}_{2}$ - és $\mathrm{NH}_{4}$-acetát + EDTAoldható (LE) kálium mennyisége $(\mathrm{mg} / \mathrm{kg})$ az integrált és ökológiai termesztési mód függvényében (a tavaszi és őszi mintavételek átlagában, $\mathrm{n}=15$ ) (2002-2004)

\begin{tabular}{|c|c|c|c|c|c|}
\hline \multirow[t]{2}{*}{$\begin{array}{l}\text { Termesztési } \\
\text { mód }\end{array}$} & $\begin{array}{l}(2) \\
\text { Orto- } \\
\mathrm{PO}_{4}{ }^{3-} \\
\end{array}$ & $\begin{array}{c}(3) \\
\text { Szerves- } \\
\mathrm{PO}_{4}{ }^{3-} \\
\end{array}$ & $\begin{array}{c}(3) \\
\text { Összes- } \\
\mathrm{PO}_{4}^{3-} \\
\end{array}$ & $\begin{array}{c}\stackrel{(4)}{\mathrm{CaCl}_{2-}} \\
\text { oldható } \mathrm{K} \\
\end{array}$ & $\begin{array}{c}\text { (5) } \\
\mathrm{NH}_{4} \text {-acetát }+ \\
\text { EDTA-oldható K }\end{array}$ \\
\hline & \multicolumn{5}{|c|}{$\mathrm{mg} / \mathrm{kg}$} \\
\hline \multicolumn{6}{|c|}{2002 tavasz } \\
\hline a) integrált & 8,22 & 0,64 & 8,86 & 239 & 359 \\
\hline b) ökológiai & 4,90 & 0,77 & 5,67 & 173 & 292 \\
\hline c) $\mathrm{SzD}_{5 \%}$ & 1,45 & 0,16 & 1,49 & 27,8 & 33,4 \\
\hline \multicolumn{6}{|c|}{2002 ösz } \\
\hline a) integrált & 8,41 & 0,73 & 9,13 & 230 & 366 \\
\hline b) ökológiai & 4,50 & 0,79 & 5,29 & 167 & 280 \\
\hline c) $\mathrm{SzD}_{5 \%}$ & 1,56 & 0,17 & 1,53 & 22,7 & 30,8 \\
\hline \multicolumn{6}{|c|}{2003 tavasz } \\
\hline a) integrált & 8,83 & 0,82 & 9,85 & 237 & 316 \\
\hline b) ökológiai & 4,27 & 0,72 & 4,99 & 178 & 241 \\
\hline c) $\mathrm{SzD}_{5 \%}$ & 1,39 & 0,12 & 1,45 & 25,6 & 30,3 \\
\hline \multicolumn{6}{|c|}{2003 ösz } \\
\hline a) integrált & 8,55 & 0,76 & 9,31 & 191 & 258 \\
\hline b) ökológiai & 4,33 & 0,69 & 5,02 & 182 & 231 \\
\hline c) $\mathrm{SzD}_{5 \%}$ & 1,32 & 0,14 & 1,44 & 5,67 & 14,1 \\
\hline \multicolumn{6}{|c|}{2004 tavasz } \\
\hline a) integrált & 9,22 & 0,37 & 9,59 & 171 & 300 \\
\hline b) ökológiai & 3,61 & 0,23 & 3,84 & 168 & 281 \\
\hline c) $\mathrm{SzD}_{5 \%}$ & 1,78 & 0,16 & 1,79 & 13,0 & 25,7 \\
\hline \multicolumn{6}{|c|}{2004 ösz } \\
\hline a) integrált & 7,01 & 0,16 & 7,17 & 140 & 236 \\
\hline b) ökológiai & 3,68 & 0,09 & 3,77 & 141 & 239 \\
\hline c) $\mathrm{SzD}_{5 \%}$ & 1,34 & 0,12 & 1,35 & 10,2 & 17,6 \\
\hline d) Integrált átlag & 8,37 & 0,58 & 8,99 & 201 & 306 \\
\hline e) Ökológiai átlag & 4,22 & 0,55 & 4,76 & 168 & 261 \\
\hline
\end{tabular}


Az említett különbség, a vizsgált szerves- és szervetlen-P frakciók közül a szervetlen foszfátoknak tulajdonítható.

Az eltérő gazdálkodású területek talajában mért szervetlen-foszfát-tartalom aránya ugyanis 1,7-2,5 között változott. A szerves foszfátok aránya az eltérő termesztésü területek között kevésbé volt differenciált.

Értékében szignifikáns különbséget nem tapasztaltunk a két gazdálkodási mód függvényében (3. táblázat).

A vizsgált P-frakciók mennyiségében mutatkozó tendenciák az alkalmazott tápanyagpótlási, trágyázási gyakorlattal magyarázhatóak és összhangban vannak a 0,01 $M \mathrm{CaCl}_{2}$-ban oldható szerves-, ill. szervetlen-N frakciók arányaival (2., ill. 3. táblázat).

A N- és P-vizsgálati eredményekből összefoglalóan megállapíthatjuk, hogy az ökológiai gazdálkodású területen mért kisebb ásványi N- és P-frakciók a területre jellemző kedvezőtlen tápanyag-érvényesülési folyamatokra hívják fel a figyelmet, ami összhangban van az ebben az ültetvényrészben kapott kisebb terméseredményekkel (GONDA, 2004).

A talaj 0,01 $\mathrm{M} \mathrm{CaCl}_{2}$-ban oldható $\mathrm{K}$-tartalma a mintavételek idejének átlagában 201, ill. $168 \mathrm{mg} / \mathrm{kg}$-nak adódott az integrált és az ökológiai ültetvényrész talajában. $\mathrm{Az}$ integrált területen mért nagyobb K-tartalom a kezelésekkel kijuttatott tápelemmennyiségekkel nem magyarázható. A kapott adatok valószínűleg a fölös mennyiségű kálium mélyebb rétegekbe mosodásával magyarázható (PAPP \& TAMÁSI, 1979).

A Lakanen-Erviö (LE) kivonatban mért elemkoncentrációk alapján a következö megállapitások tehetöek:

A talaj LE-oldható K-tartalma a mintavételek idejének átlagában 306, ill. 261 $\mathrm{mg} / \mathrm{kg}$-nak adódott az integrált és az ökológiai ültetvényrész talajában.

A két gazdálkodási mód talajának LE-oldható K-tartalmában mutatkozó különbség a 0,01 $M \mathrm{CaCl}_{2}$-os kivonószer esetén mért értékekhez hasonló mértékü és tendenciájú. A megfelelö adatpárok összehasonlításakor a két kivonószer közötti különbség szembeötlő (3. táblázat). A Lakanen-Erviö kivonat mind az integrált, mind az ökológiai ültetvényrészben, fóátlagban mintegy 52-55\%-kal több káliumot tartalmaz, mint a $0,01 M \mathrm{CaCl}_{2}$ kivonószer azonos oldatai.

Mindkét talajkivonószerrel - homoktalajra nézve - jelentős K-tartalmat kaptunk a vizsgált ültetvényrészek talajában. Adataink felhívják a figyelmet, hogy ezen a savanyú kémhatású, kolloidokban szegény, csekély megkötő képességgel rendelkező homoktalajon - a megfelelö, több évtizedes tápanyagpótlási gyakorlat miatt jelentős mennyiségü kálium lehet adszorbeált, ill. gyenge savban oldható formában jelen.

A három év tavaszi és őszi átlagadatai alapján a talaj LE-oldható Ca-tartalma az integrált ültetvényrész talajában szignifikánsan nagyobb volt, mint az ökológiai termesztés talajaiban mért érték (4. táblázat).

Az integrált ültetvényrész talajának LE-oldható Ca-tartalma a mintavételek idejének átlagában $579 \mathrm{mg} / \mathrm{kg}$, míg az ökológiai ültetvényrészé $451 \mathrm{mg} / \mathrm{kg}$ volt. 


$$
\text { 4. táblázat }
$$

A Lakanen-Erviö kivonatban ( $\mathrm{NH}_{4}$-acetát + EDTA-) oldható elemtartalmak (mg/kg) az integrált és ökológiai termesztési módok függvényében (a tavaszi és őszi mintavételek átlagában, $\mathrm{n}=15)(2002-2004)$

\begin{tabular}{|c|c|c|c|c|c|}
\hline $\begin{array}{c}\text { (1) } \\
\text { Termesztési mód } \\
\end{array}$ & $\mathrm{Ca}$ & $\mathrm{Mg}$ & $\mathrm{Mn}$ & $\mathrm{Cu}$ & $\mathrm{Zn}$ \\
\hline \multicolumn{6}{|c|}{2002 tavasz } \\
\hline a) integrált & 625 & 85,0 & 62,7 & 4,00 & 3,04 \\
\hline b) ökológiai & 426 & 51,9 & 59,6 & 3,54 & 2,02 \\
\hline c) $\mathrm{SzD}_{5 \%}$ & 86,5 & 14,5 & 3,20 & 0,38 & 0,51 \\
\hline \multicolumn{6}{|c|}{2002 ösz } \\
\hline a) integrált & 442 & 78,9 & 65,0 & 3,60 & 2,79 \\
\hline b) ökológiai & 392 & 54,8 & 68,0 & 3,20 & 1,58 \\
\hline c) $\mathrm{SzD}_{5 \%}$ & 45,1 & 11,1 & 4,91 & 0,31 & 0,45 \\
\hline \multicolumn{6}{|c|}{2003 tavasz } \\
\hline a) integrált & 666 & 94,9 & 65,7 & 4,42 & 2,47 \\
\hline b) ökológiai & 495 & 66,1 & 60,4 & 3,47 & 1,92 \\
\hline c) $\mathrm{SzD}_{5 \%}$ & 104,1 & 13,3 & 3,14 & 0,62 & 0,26 \\
\hline \multicolumn{6}{|c|}{2003 ösz } \\
\hline a) integrált & 646 & 91,6 & 57,6 & 3,68 & 3,75 \\
\hline b) ökológiai & 458 & 48,6 & 62,0 & 3,14 & 1,70 \\
\hline c) $\mathrm{SzD}_{5 \%}$ & 90,8 & 15,3 & 4,93 & 0,43 & 0,71 \\
\hline \multicolumn{6}{|c|}{2004 tavasz } \\
\hline a) integrált & 503 & 86,5 & 67,4 & 3,83 & 3,53 \\
\hline b) ökológiai & 437 & 59,3 & 65,6 & 3,81 & 1,62 \\
\hline c) $\mathrm{SzD}_{5 \%}$ & 70,4 & 14,9 & 7,34 & 0,32 & 0,79 \\
\hline \multicolumn{6}{|c|}{2004 ösz } \\
\hline a) integrált & 591 & 87,6 & 56,2 & 3,88 & 2,84 \\
\hline b) ökológiai & 499 & 48,5 & 58,3 & 3,74 & 1,81 \\
\hline c) $\mathrm{SzD}_{5 \%}$ & 89,5 & 16,8 & 5,59 & 0,42 & 0,40 \\
\hline d) Integrált átlag & 579 & 87,4 & 62,4 & 3,90 & 3,07 \\
\hline e) Ökológiai átlag & 451 & 54,9 & 62,3 & 3,48 & 1,78 \\
\hline
\end{tabular}

Adataink az integrált ültetvényrészben végzett mésztrágyázás hatásával magyarázhatók.

Az integrált gazdálkodású terület feltalajának LE-oldható Mg-tartalma szignifikánsan, a mintavételek idejének fóátlagában mintegy 60\%-kal meghaladta az ökológiai gazdálkodású területen mért értéket (4. táblázat).

A talaj LE-oldható Mn-tartalma a mintavételek idejének fóátlagában $62 \mathrm{mg} / \mathrm{kg}$ nak adódott, függetlenül a vizsgált gazdálkodási módoktól. Az LE-kivonat nagy Mn-tartalma - összhangban a talaj pH-értékekkel - rámutat a savanyú kémhatású homoktalajokon jellemzően kialakuló, jelentős könnyen oldható Mn-tartalomra.

Az integrált és az ökológiai ültetvényrész feltalajának LE-oldható Cu-tartalma 3,1-4,4 mg/kg között változott a gazdálkodási mód, ill. a mintavétel idejének függ- 
vényében. A talaj Mn-tartalmához hasonlóan nem kaptunk jelentős különbséget a két ültetvényrészben mért Cu-tartalomra nézve. Értéke az integrált ültetvényrészben a mintavételek idejének átlagában $3,9 \mathrm{mg} / \mathrm{kg}$, míg az ökológiai ültetvényben 3,48 $\mathrm{mg} / \mathrm{kg}$ volt (4. táblázat).

A talaj LE-oldható Zn-tartalma a Mn- és Cu-tartalomtól eltérően jelentős eltérést mutat a gazdálkodási módtól függően. Az integrált terület talajának LE-oldható Zn-tartalma átlagban közel másfél-kétszer nagyobb, mint az ökológiai gazdálkodású terület Zn-tartalma. A különbség, valószínüleg az integrált területen alkalmazott NPK-mütrágyázással hozható kapcsolatba. Az NPK komplex mütrágyák ugyanis esetenként jelentős mennyiségủ cinket tartalmazhatnak, ahogy erre a termékismertetők, valamint több szerző is rámutat (CSATHÓ, 1994; KÁDÁR \& TURÁN, 2002).

A Lakanen-Erviö kivonatban mért Cu- és Zn-koncentrációk megfelelnek a talajtípusra jellemzö kis humusztartalomnak, ill. pH- és kötöttségi értékeknek (MOLNÁROS \& GRÁCZOL, 2000).

\section{Összefoglalás}

A DE ATC Debrecen-Pallag Kísérleti Telepén 1997-ben, M 26-os alanyon $4 \times 1,5 \mathrm{~m}$ sor- és tőtávolságra telepített integrált és ökológiai gazdálkodású alma fajtagyüjtemény feltalajának $(0-20 \mathrm{~cm})$ tápanyag-koncentrációit vizsgáltuk két talajkivonószer segítségével. A vizsgált terület homok textúrájú, kovárványos barna erdőtalaj. Arany-féle kötöttsége 28; $\mathrm{CaCl}_{2}-\mathrm{os} \mathrm{pH}$-ja 4,62; humusztartalma 0,59\%.

Az ökológiai ültetvényrész 2000 és 2002 tavaszán csak szervestrágyázásban (50 t/ha) részesült, míg az integrált ültetvényrész 1997-2003 között minden évben, lombhullás után $250 \mathrm{~kg}$ /ha NPK komplex (16,5-16,5-16,5) mütrágyát kapott. Ebben az ültetvényrészben minden évben kiegészítésként $50 \mathrm{~kg}$ /ha N-hatóanyagtartalmú $\mathrm{NH}_{4} \mathrm{NO}_{3} ; 2002$ öszén $4 \mathrm{t}$ /ha mésztrágya (cukorgyári mésziszap), valamint 2003 novemberében 25 t/ha szerves trágya is kijuttatásra került. 2004-ben egyik ültetvényrészben sem történt tápanyagpótlás.

A könnyen oldható és mobilizálható makroelemek és a növénytermesztés szempontjából lényeges vegyületformáik vizsgálatára a hazánkban is egyre inkább elterjedt $0,01 \mathrm{M} \mathrm{CaCl}_{2}$ talajkivonószert, míg a felvehető, ill. mobilisnak minősülő mikroelemek és a kálium koncentrációjának meghatározására a szakirodalomban Lakanen-Erviö kivonószerként ismert $\mathrm{NH}_{4}$-acetát+EDTA-t használtuk.

Eredményeink alapján megállapítható, hogy a $0,01 M \mathrm{CaCl}_{2}$-oldható egyes $\mathrm{N}$ - és P-frakciók mennyiségében jelentős különbség mutatkozik a két gazdálkodási forma talajai között: Az ásványi N- és P-formák az integrált gazdálkodású terület talajaiban nagyobb mennyiséget és részarányt képviselnek, mint az ökológiai gazdálkodású terület talajaiban. A szerves-N- és P-frakciókban ilyen mértékủ különbséget a két gazdálkodási forma területéről származó talajmintákban nem tapasztatunk.

Megállapítható továbbá, hogy a $0,01 M \mathrm{CaCl}_{2}$-oldható szerves-N-, ill. P-frakció részaránya jelentős - az ásványi frakciókkal összemérhető mindkét ültetvényrész talajában. 
Az integrált terület talajának Lakanen-Erviö kivonatában mért Ca-, $\mathrm{Mg}-, \mathrm{Cu}-$ és Zn-koncentrációk egyaránt szignifikánsan meghaladták az ökológiai gazdálkodású terület talajában mért értékeket. Nem kaptunk viszont lényeges különbséget a két termesztési forma talajának Mn-tartalmában. A mikroelem-koncentrációk értékei a talajtípus tulajdonságaiból adódóan kicsik voltak, kivételt csak a Mn-tartalom jelentett, ami rávilágított a savanyú kémhatású homoktalajokon jelenlévő, jelentős oldható, ill. felvehető Mn-tartalomra. A két kivonószerben mért K-koncentrációk összehasonlítása alapján megállapítottuk, hogy ebben a kolloidban és humuszban szegény, kis megkötő képességü homok textúrájú talajban is jelentős K-készletek lehetnek adszorbeált, ill. gyenge savban oldható állapotban jelen.

A meghatározott tápanyag-koncentrációk, a mangánt kivéve - mindkét kivonatban egyaránt - tükrözték a vizsgált gazdálkodási módokban mutatkozó tápanyagpótlási különbségeket.

A gazdálkodási módok összehasonlító vizsgálatában mért tápanyagok mennyiségi viszonyai - különös tekintettel a vizsgált szerves frakciók részarányára - rámutatnak és megerősítik, hogy kedvezőtlenebb adottságú területeken, ökológiai gazdálkodást pusztán szervestrágyázásra alapozni nem lehet. Ezeken a területeken megfelelő mennyiségü és minőségü termést csak a talajtulajdonságokat is javító tápanyag-gazdálkodási gyakorlattal kaphatunk.

Kulcsszavak: integrált és ökológiai gazdálkodás, talajvizsgálat, makro- és mikroelemek

\section{Irodalom}

BALÁzs, K. et al., 1997. Possibility and problems of organic apple growing in Hungary. Entomological Research in Organic Agriculture. 25. 223-232.

BloOMERS, L., 1994. Integrated pest management in European apple orchards. Ann. Rev. of Entomol. 39. 213-241.

Bohn, H. L., MCNEAL, B. L. \& O'ConNoR, G. A., 1985. A pH és a makrotápelemek. In: Talajkémia. 240-241. Mezőgazdasági Kiadó-Gondolat Kiadó. Budapest.

BUBÁN T., ZATYKÓ I. \& GONDA I., 1979. A nitrogéntrágyázás időzitésének hatása az almafák virágszerveinek kialakulására. In: Újabb eredmények a gyümölcstermesztésben. 1. (6) 29-41.

BuZÁs I. (szerk.), 1988. A talajok fizikai-kémiai és kémiai vizsgálati módszerei. Mezögazdasági Kiadó. Budapest.

CSATHÓ P., 1994. A környezet nehézfém szennyezettsége és az agrártermelés. MTA Talajtani és Agrokémiai Kutató Intézete. Budapest.

ElLis, M. A., FereE, D. C. \& MADDEN, L. V., 1998. Effects of an apple scab-resistant cultivar on use patterns of inorganic and organic fungicides and economics of disease control. Plant Disease. 82. 428-433.

FILEP GY., 1995. Talajvizsgálat. DATE Egyetemi jegyzet. Debrecen.

Glower, J. D., Reganold, J. P. \& AnDRews, P. K., 2000. Systematic method for rating soil quality of conventional, organic, and integrated apple orchards in Washington State. Agriculture, Ecosystems and Environment. 80. 29-45. 
GONDA I., 1979. A metszés időzítése, mértéke és a fák kondíciójának kölcsönhatásai. In: Újabb eredmények a gyümölcstermesztésben. 1. (6) 21-28.

GONDA, I., 2003. Production technology and fruit tree nutrition. International Journal of Horticultural Science. 9. 39-42.

GONDA I., 2005. Klímaváltozások, gyümölcs művelési rendszerek és termesztéstechnológiák termésbiztonsági összefüggései. AGRO-21 Füzetek 39. 3-23.

GondA, I., HolB, I. J. \& BitSKEY, K., 2000. Rate of scab infection and quality parameters of apple fruit in organic and integrated production systems. International Journal of Horticultural Science. 6. (4) 63-67.

GONDA I., HOLB, I. \& BITSKEY K., 2001. Előzetes adatok a metszés erőssége és a károsítás mértéke közötti összefüggésekről integrált és ökológiai almatermesztési technológiákban. Debreceni Egyetem Agrártudományi Közlemények. 1. 47-52.

HolB, I. J., 2000. Disease progress of apple scab caused by Venturia inaequalis in environmentally friendly growing systems. International Journal of Horticultural Science. 6. (4) 56-62.

Holb, I. J. \& Heisne, B., 2001. Evaluating primary scab control in organic apple production. European Journal of Horticultural Science. 66. (5) 254-261.

Holb, I. J., HeiJne, B. \& Jeger, M. J., 2003. Summer epidemics of apple scab: the relationship between measurements and their implications for the development of predictive models and threshold levels under different disease control regimes. Journal of Phytopathology. 151. (6) 335-343.

Holb, I. J., HeiJne, B. \& JEGER, M. J., 2004. Overwintering of conidia of Venturia inaequalis and the contribution to early epidemics of apple scab. Plant Disease. 88. 751-757.

Holb, I. J., Jong, P. F. DE \& HeiJne, B., 2003. Efficacy and phytotoxicity of lime sulphur in organic apple production. Annals of Applied Ecology. 142. (2) 225 233.

HOPKINS-CLARK, J. S., 1995. A comparison of organic, integrated and conventional soil management systems in a commercial apple orchard. MSc. Thesis. Washington State University. Pullman, WA.

HoubA, V. J. G. et al., 1986. Comparison of soil extrctions by $0,01 \mathrm{CaCl}_{2}$ by EUF and by some conventional extraction procedures. Plant and Soil. 96. 433-437.

KÁDÁR I. \& TURÁN T., 2002. P-Zn kölcsönhatás mészlepedékes csernozjom talajon kukorica monokultúrában. Agrokémia és Talajtan. 51. 381-394.

LAZÁNYI, J., LOCH, J. \& JÁSZBERÉNYI, I., 2002. Analysis of $0.01 M \mathrm{CaCl}_{2}$ soluble organic nitrogen in the treatments of Westsik's crop rotation experiment. Agrokémia és Talajtan. 51. 79-88.

LAZÁNYI, J., LOCH, J. \& NAGY, P. T., 2003. Importance of $0,01 \mathrm{M} \mathrm{CaCl}_{2}$ soluble organic nitrogen in the characterisation of N-supply in the treatments of Westsik's crop rotation experiment. In: Proc. $14^{\text {th }}$ Int. CIEC Symp. „Fertilizers in Context with Resource Management in Agriculture. (Eds: SCHNUG, E. et al.) 1. 104-112. Krausz-Könyv BT.

Loch J., 1999. A talajok könnyen oldható szervetlen és szerves N, P, S frakciói. T017043 számú OTKA téma zárójelentése.

MolnÁROS I. \& GRÁCZOL CS., 2000. A talajok réz-, cink- és mangántartalmának összehasonlítása KCl-EDTA, Lakanen-Erviö és töménysavas feltárással a Talajvédelmi 
Információs és Monitoring Rendszer vizsgálatai alapján. Agrokémia és Talajtan. 49. $127-144$.

NAGY P. T., 2000. Égetéses elven müködő elemanalizátor alkalmazhatósága talaj- és növényvizsgálatokban. Agrokémia és Talajtan. 49. 521-534.

PAPP J. \& TAMÁSI J., 1979. Gyümölcsösök talajmüvelése és tápanyagellátása. Mezőgazdasági Kiadó. Budapest.

SARKADI J., 1975. A műtrágyaigény becslésének módszerei. Mezőgazdasági Kiadó. Budapest

SELÉNDY Sz., 1997. Biogazdálkodás az ökológiai szemléletü gazdálkodás kézikönyve. Mezőgazdasági Szaktudás Kiadó. Budapest

SOlTÉSZ M. \& SZABÓ T., 1997. Alma. In: Integrált gyümölcstermesztés. (Szerk.: SOLTÉSZ M.) 428-437. Mezőgazda Kiadó. Budapest.

SolTi G., 2000. Talajjavítás és tápanyag-utánpótlás az ökogazdálkodásban. Mezőgazda Kiadó. Budapest

WERNER, M. R., 1997. Soil quality characteristics during conversion to organic orchard management. Applied Soil Ecology. 5. 151-167.

Érkezett: 2005. május 5. 


\title{
Comparison of the Macro- and Microelement Contents of the Soil in Apple Orchards
}

\author{
P. T. NAGY \\ Department of Agricultural Chemistry, Centre of Agricultural Sciences, University of Debrecen
}

\section{Summary}

In a three-year study carried out at the Debrecen-Pallagi nursery of the University of Debrecen, the nutrient contents, humus content and $\mathrm{pH}$ of the soil were determined in integrated and organic apple orchards established on brown forest soil with thin interstratified layers of colloid and sesquioxide accumulation. The organic orchard was only given organic manure (50 t/ha) in spring 2000 and 2002, while the integrated orchard was treated with $250 \mathrm{~kg} /$ ha complex NPK fertilizer (16.5-16.5-16.5) every year between 1997 and 2003 after the leaves had fallen. An additional $50 \mathrm{~kg} / \mathrm{ha} \mathrm{N}$ active agent as $\mathrm{NH}_{4} \mathrm{NO}_{3}$ was applied every year, while $4 \mathrm{t} /$ ha lime fertilizer (carbonation mud) was provided in autumn 2002 and 25 t/ha organic manure in November 2003. In 2004 no fertilizer was given to either orchard.

The available forms of $\mathrm{N}\left(\mathrm{NO}_{3}{ }^{-}, \mathrm{NH}_{4}{ }^{+}\right.$, organic $\mathrm{N}$ and total $\mathrm{N}$ ) and $\mathrm{P}$ (ortho-, organic and total- $\mathrm{PO}_{4}{ }^{3-}$ ) were determined after extraction with $0.01 \mathrm{M} \mathrm{CaCl}_{2}$, while the $\mathrm{Ca}, \mathrm{Mg}$ and microelement $(\mathrm{Mn}, \mathrm{Cu}, \mathrm{Zn})$ content of the soil was extracted with $\mathrm{NH}_{4}$-acetate +EDTA (Lakanen-Erviö extractant). Potassium was measured in both extractants.

The results showed that the inorganic, organic and total soluble nitrogen in the soil were significantly higher $(\mathrm{P}=0.05)$ in the integrated orchard than in the organic one. It was found that the quantity and ratio of the organic $\mathrm{N}$ fraction was comparable with that of the inorganic $\mathrm{N}$ forms. The ortho-phosphate and total $\mathrm{P}$ fractions were significantly higher $(\mathrm{P}=0.05)$ in the integrated apple orchard than in the organic orchard, while there was no significant difference in the organic $\mathrm{P}$ quantity. The potassium data showed that both the integrated and organic orchards contained a satisfactory amount of adsorbed $\mathrm{K}$ in spite of the poor colloid content and high soil acidity. The $\mathrm{Ca}, \mathrm{Mg}$, $\mathrm{Co}$ and $\mathrm{Zn}$ contents of the integrated soils were significantly higher $(\mathrm{P}=0.05)$ than in the organic orchard. For Mn, however, no substantial difference was found between the integrated and organic orchards. With the exception of $\mathrm{Mn}$, the nutrient concentrations reflected the differences in the nutrient management of the integrated and organic apple orchards.

Table 1. Treatments applied in the integrated and organic apple orchards and the quantities of nutrients involved (estimated means).

Table 2. Quantity of $0.01 \mathrm{M} \mathrm{CaCl}_{2}$-soluble $\mathrm{N}$ forms, humus content and $\mathrm{pH}$ as a function of the management method (integrated or organic). (1) Management method. a) Integrated; b) Organic; c) LSD $_{5 \%}$; d) Integrated mean; e) Organic mean. (2) Organic N. (3) Total N. (4) Humus, \%.

Table 3. Quantity of $0.01 \mathrm{M} \mathrm{CaCl}_{2}$-soluble $\mathrm{P}$ forms and $0.01 \mathrm{M} \mathrm{CaCl}_{2}$ - and $\mathrm{NH}_{4}$ acetate+EDTA-soluble (LE) $\mathrm{K}$ forms as a function of the management method (integrated or organic) (averaged over the sampling dates, $\mathrm{n}=15$ ).

Table 4. Element contents soluble in Lakanen-Erviö extractant $\left(\mathrm{NH}_{4}\right.$-acetate+ EDTA) as a function of the management method (integrated or organic).

Fig. 1. Siting of the apple orchards. 